\title{
Homing of antigen-presenting cells in head kidney and spleen - salmon head kidney hosts diverse APC types
}

\section{Dimitar B. Iliev ${ }^{1}$ *, Hanna Thim ${ }^{1}$, Leidy Lagos ${ }^{1}$, Randi Olsen ${ }^{2}$ and Jorunn B. Jørgensen ${ }^{1}$}

${ }^{1}$ Norwegian College of Fisheries Science, University of Tromsø, Tromsø, Norway

${ }^{2}$ Department of Medical Biology, University of Tromsø, Tromsø, Norway

\section{Edited by:}

Ken J. Ishii, National Institute of

Bimedical Innovation, Japan

\section{Reviewed by:}

Ken J. Ishii, National Institute of Bimedical Innovation, Japan

Mayda Gursel, Middle East Technical

University, Turkey

\section{${ }^{*}$ Correspondence:}

Dimitar B. lliev, Norwegian College of Fishery Science, University of Tromso, Breivika, N-9037Tromsø, Norway e-mail:dimi.iliev@gmail.com
Lymph nodes and spleen are major organs where mammalian antigen-presenting cells (APCs) initiate and orchestrate Ag-specific immune responses. Unlike mammals, teleosts lack lymph nodes and an interesting question is whether alternative organs may serve as sites for antigen presentation in teleosts. In the current study, fluorescent ovalbumin (Ova) and $\mathrm{CpG}$ oligonucleotides (ODNs) injected intra-abdominally were detected in significant numbers of salmon head kidney (HK) MHCll+ cells over a period of 2 weeks while in spleen the percentage of these was transient and declined from day 1 post injection. In vitro studies further shed light on the properties of the diverse $\mathrm{MHCll}+$ cell types found in HK. The ultrastructure of a subpopulation of $\mathrm{MHCll}+$ cells with a high capacity to endocytose and process Ova indicated that these were able to perform constitutive macropinocytosis. Upon stimulation with $\mathrm{CpG}$ ODNs these cells upregulated CD86 and gave very high levels of TNF mRNA indicating that these are professional APCs, related to macrophages and dendritic cells (DCs). A subpopulation of HK granulocytes expressed high levels of surface $\mathrm{MHCll}$ and upon $\mathrm{CpG}$ stimulation upregulated most of the tested APC marker genes. Although these granulocytes expressedTNF weakly, they had relatively high basal levels of IL-1 $\beta$ mRNA and the CpG stimulation upregulated IL-1 $\beta$, along with its signaling and decoy receptors, to the highest levels as compared to other HK cell types. Interestingly, the high expression of IL-1 $\beta$ mRNA in the granulocytes correlated with a high autophagy flux as demonstrated by LC3-II conversion. Autophagy has recently been found to be implicated in IL-1 $\beta$ processing and secretion and the presented data suggests that granulocytes of salmon, and perhaps other teleost species, may serve as a valuable model to study the involvement of autophagy in regulation of the vertebrate immune response.

Keywords: MHCII, APC, granulocytes, Atlantic salmon, CpG oligonucleotides, IL-1 $\beta$, TNF, autophagy

\section{INTRODUCTION}

Antigen-presenting cells (APCs) are specialized to take up, process and present protein antigens $(\mathrm{Ag})$ associated with MHCII molecules to Ag-specific T-cells. Professional APCs include dendritic cells (DCs), macrophages, and B-cells of which the DCs are distinguished by their high co-stimulatory capacity (Hamilos, 1989; Thery and Amigorena, 2001). APCs are distributed throughout the organism, including the peripheral tissues where they capture inbound Ags derived from potentially pathogenic agents. In order to achieve full co-stimulatory capacity, APCs need to be activated through innate immune receptors such as toll-like receptors (TLRs) which recognize conserved molecular structures produced by microorganisms and viruses (Thery and Amigorena, 2001). In mammals, exposure of DCs to these pathogen-associated molecular patterns (PAMPs) may trigger a process of maturation during which the antigen-loaded DCs migrate toward the secondary immune organs, upregulate MHCII-associated Ag peptides and co-stimulatory molecules on their surface and downregulate their capacity to endocytose Ag (Kaisho and Akira, 2003). In mammals, the major organs where maturing DCs migrate and which provide proper environment for Ag presentation are the lymph nodes and the spleen.
The adaptive immune system has evolved at the level of early jawed vertebrates and most of its elements described in mammals, such as Ag-specific B- and, T-cell receptors and antibodies are also found in teleosts (Pancer and Cooper, 2006). In addition, a T-cell-dependent $\mathrm{Ag}$ response has been described in teleosts (Miller et al., 1986) and PAMPs, such as CpG oligonucleotides (ODNs), have shown a potential to induce maturation of salmon APCs in vitro (Iliev et al., 2010). Cells resembling mammalian DCs have been described in fish (Lovy et al., 2009; Aghaallaei et al., 2010; Lugo-Villarino et al., 2010; Bassity and Clark, 2012) and authors have suggested that the melanomacrophage centers which are found in the spleen and the head kidney (HK) (anterior kidney, pronephros) of different teleosts (Tsujii and Seno, 1990) may serve as sites for Ag presentation (Agius and Roberts, 2003). Still, there are considerable differences between the mammalian and the teleost immune systems - for example, absence of lymph nodes and classical Ig class switch in teleosts. Therefore, more detailed knowledge about the phenotype and the function of piscine APCs will help gain insight into the evolution of the vertebrate adaptive immune system and will provide valuable information for development and optimization of immunotherapies for aquaculture use. 
In an earlier study, we found that Atlantic salmon HK hosts distinct $\mathrm{MHCII}+$ cell types including $\mathrm{MHCII}+$ leukocytes which endocytosed large amounts of dextran and a population of granular cells with lower capacity to take up dextran but with high levels of surface MHCII as shown by staining with an antibody specific for the MHCII beta chain (Iliev et al., 2010). Additionally, the HK harbored MHCII/Ig double-positive cells, resembling B-cells.

In light of these findings, the current study has been intended to further characterize salmon APCs in regard to their ability to migrate to $\mathrm{HK}$ and spleen following in vivo uptake of Ag, their morphology, and their potential to express immune genes including APC markers, cytokines, and cytokine receptors. Fluorescent ovalbumin (Ova-FITC) injected in the abdominal cavity was observed both in HK and spleen leukocytes 1 day post injection, while at latter time points (5 and 14 days) it was found exclusively in $\mathrm{MHCII}+/ \mathrm{IgM}-\mathrm{HK}$ cells. When HK cells were stimulated in vitro, distinct gene expression profiles were detected in different $\mathrm{HK}$ $\mathrm{MHCII}+$ cell types. The cells which endocytosed high amounts of Ova expressed the highest levels of CD86 and TNF mRNA suggesting that these are maturing APCs. On the other hand, a population of cells with morphology of polymorphonuclear granulocytes which expressed high levels of surface MHCII and did not take up significant amounts of Ova, upregulated very high levels of IL-1 $\beta$ mRNA along with APC marker genes including CD83, CD40, and B7-H1 but they expressed relatively low levels of CD86. Autophagy has recently been found to be involved in production and secretion of IL-1 $\beta$ (Dupont et al., 2011) and autophagy flux analysis using sorted cell populations showed that the intensity of the process was highest in the HK granulocytes suggesting that these cells might be specialized in production and secretion of this cytokine.

\section{MATERIALS AND METHODS \\ FISH}

Atlantic salmon (Salmo salar) strain AquaGen standard (Aqua Gen, Kyrksæterøra, Norway) were obtained from the Tromsø Aquaculture Research Station (Tromsø, Norway). The fish were kept at about $10^{\circ} \mathrm{C}$ in tanks supplied with running filtered water and were fed on commercial, dry food (Skretting, Stavanger, Norway). All experiments were approved by the national committee for animal experimentation (Forsøksdyrutvalget, Norway) and performed according to its guidelines.

\section{REAGENTS}

Phosphorothioate-modified CpG-B ODNs (5'-TCGTCGTTTTGT CGTTTTGTCGTT-3') were purchased from Thermo Scientific. The antiserum against the $\beta$-chain of salmon MHCII was previously described (Iliev et al., 2010). The antibody against salmonid IgM was obtained from CedarLane Labs, ON, Canada. A secondary goat anti-rabbit antibody conjugated with AlexaFluor546, Ova-Alexa647, DQ Ova, and LysoSensor ${ }^{\mathrm{TM}}$ Green DND-189 were purchased from Life technologies. Goat anti-rabbit-horseradish peroxidase antibody was obtained from Santa Cruz Biotechnology and the eEF2 polyclonal antibody was purchased from Cell Signaling Technology. Polyclonal LC3 antibody, dextran-Cascade Blue, Ova-FITC, and May Grünwald-Giemsa reagents were obtained from Sigma.

\section{ISOLATION OF LEUKOCYTES FROM ATLANTIC SALMON}

Three groups of 15 individuals of $\sim 100 \mathrm{~g}$ were injected intraabdominally with $100 \mu \mathrm{l}$ of PBS, $500 \mu \mathrm{g}$ of Ova-FITC, or with, $500 \mu \mathrm{g}$ of Ova-FITC $+50 \mu \mathrm{g}$ of CpG-Cy5. HK and spleen leukocytes were isolated 1,5 , and 14 days post injection as described (Iliev et al., 2010). Briefly, the HK and the spleen tissues were passed through $100-\mu \mathrm{m}$ pore size cell strainers (Falcon) in L-15 medium containing penicillin $(10 \mathrm{U} / \mathrm{ml})$, streptomycin $(10 \mu \mathrm{g} / \mathrm{ml}), 2 \%$ fetal bovine serum (FBS), and heparin $(20 \mathrm{U} / \mathrm{ml})$. The resulting suspension was placed on a $25 / 54 \%$ discontinuous Percoll gradient and centrifuged at $400 \times \mathrm{g}$ for $40 \mathrm{~min}$ at $4{ }^{\circ} \mathrm{C}$. The cells at the interface were collected and washed twice in L-15 medium before further use. For the in vitro experiments, the density of the leukocyte suspensions was adjusted to $7 \times 10^{6}$ cells $/ \mathrm{ml}$ and the cells were further incubated in 24 -well plates in L-15, 5\% FBS.

\section{FLOW CYTOMETRY}

Cells were pelleted at $4{ }^{\circ} \mathrm{C}$ and the staining was performed on ice. The cells were washed with ice-cold PBS and incubated simultaneously with MHCII $\beta$ rabbit antiserum (1000-fold dilution) and salmon anti-IgM FITC-conjugated monoclonal antibody (200fold dilution) for $1 \mathrm{~h}$ in PBS, 5\% FBS on ice. The secondary Alexa546 goat anti-rabbit antibody was diluted to $1 \mu \mathrm{g} / \mathrm{ml}$ in PBS, $5 \%$ FBS and the cells were incubated for $30 \mathrm{~min}$ on ice prior to washing with PBS. For the in vitro endocytosis assays, HK leukocytes were incubated with $10 \mu \mathrm{g} / \mathrm{ml}$ of Ova-FITC or Ova-Alexa647, $150 \mu \mathrm{g} / \mathrm{ml}$ of dextran-Cascade blue and $2 \mu \mathrm{M}$ CpG-Cy5 ODNs for $1 \mathrm{~h}$. Prior to sorting, the whole HK leukocyte population was stimulated for $24 \mathrm{~h}$ with $2 \mu \mathrm{M}$ CpG ODNs followed by $1 \mathrm{~h}$ incubation with $10 \mu \mathrm{g} / \mathrm{ml}$ of or Ova-Alexa647 prior to staining as described above. The cells were analyzed and sorted using FACSAria (Becton Dickinson).

To analyze the Ag-processing capacity of APCs found in salmon $\mathrm{HK}$, cells were incubated with $5 \mu \mathrm{g} / \mathrm{ml}$ of Ova-DQ for $4 \mathrm{~h}$. After removal of non-adherent cells, the adherent ones were detached and harvested using a 10 min treatment with PBS, 1 mM EDTA. The adherent and the non-adherent cells were stained for surface MHCII and analyzed separately with flow analysis. Ova-DQ proteolysis was detected as green fluorescence.

\section{REAL-TIME PCR (RT-PCR) ANALYSIS}

RNA from sorted cells was isolated using RNeasy Mini Kit (Qiagen). On-column DNase digestion was performed using RNaseFree DNase set (Qiagen, Hilden, Germany). For each sample $70 \mathrm{ng}$ total RNA was reverse transcribed using the TaqMan Reverse Transcription Reagents kit (Applied Biosystems). The real-time PCR (RT-PCR) reactions were prepared with Power SYBR ${ }^{\circledR}$ Green PCR Master Mix or TaqMan ${ }^{\circledR}$ Fast Universal PCR Master Mix (Applied Biosystems). The type of the reaction and the primer and the probe sequences are listed in Table 1 . The reactions were run in duplicate and included $5 \mu \mathrm{l}$ of fivefold diluted cDNA. The reaction protocol and the data analysis have been previously described (Iliev et al., 2010). EFlaB expression was used as endogenous control and the data is presented as fold difference values as compared to the non-stimulated $\mathrm{MHC}-/ \mathrm{Ig}-/ \mathrm{Ova}-$ sample. 
Table 1 | Sequences of the primers used in the PCR analysis.

\begin{tabular}{|c|c|c|c|}
\hline $\mathrm{B} 7-\mathrm{H} 1$ & $\begin{array}{l}\text { SYBR } \\
\text { green }\end{array}$ & $\begin{array}{l}\text { Fwd } \\
\text { Rev }\end{array}$ & $\begin{array}{l}\text { ACATGTGTCCAGGCTGAGGATCAA } \\
\text { ATTGTGGCAAGAGGATAGCCCTCA }\end{array}$ \\
\hline $\begin{array}{l}\text { TNF decoy } \\
\text { receptor } 3 \\
\text { (DCR3) }\end{array}$ & $\begin{array}{l}\text { SYBR } \\
\text { green }\end{array}$ & $\begin{array}{l}\text { Fwd } \\
\text { Rev }\end{array}$ & $\begin{array}{l}\text { AGCATTGCACAAAGGACCGCAA } \\
\text { ACACCTTCTGCGCCTTGAACAT }\end{array}$ \\
\hline $\begin{array}{l}\text { TNFRSF11B } \\
\text { Osteopro- } \\
\text { tegerin } \\
\text { (OPG) }\end{array}$ & $\begin{array}{l}\text { SYBR } \\
\text { green }\end{array}$ & $\begin{array}{l}\text { Fwd } \\
\text { Rev }\end{array}$ & $\begin{array}{l}\text { ACGGGCCAGTTACTCACCTGTAAT } \\
\text { TGAGAACCGAGCATTCCTCCTTGA }\end{array}$ \\
\hline CD40 & $\begin{array}{l}\text { SYBR } \\
\text { green }\end{array}$ & $\begin{array}{l}\text { Fwd } \\
\text { Rev }\end{array}$ & $\begin{array}{l}\text { ATGCCATGCCAAGAGGGTGAAT } \\
\text { ATTTGCATGGGCTGAGGCTTGT }\end{array}$ \\
\hline TNF2 & $\begin{array}{l}\text { SYBR } \\
\text { green }\end{array}$ & $\begin{array}{l}\text { Fwd } \\
\text { Rev }\end{array}$ & $\begin{array}{l}\text { TGCTGGCAATGCAAAAGTAG } \\
\text { AGCCTGGCTGTAAACGAAGA }\end{array}$ \\
\hline CD86 & $\begin{array}{l}\text { SYBR } \\
\text { green }\end{array}$ & $\begin{array}{l}\text { Fwd } \\
\text { Rev }\end{array}$ & $\begin{array}{l}\text { ACTTCACACTCGATTACGGCTGCT } \\
\text { AGCAGGAATAAGGTGACACACCGA }\end{array}$ \\
\hline IL1R1 & $\begin{array}{l}\text { SYBR } \\
\text { green }\end{array}$ & $\begin{array}{l}\text { Fwd } \\
\text { Rev }\end{array}$ & $\begin{array}{l}\text { AATGCTACTGAGAGCCATGCTGGA } \\
\text { ACTTTGAGCTGAGTGCTGTGGGTA }\end{array}$ \\
\hline IL1R2 & $\begin{array}{l}\text { SYBR } \\
\text { green }\end{array}$ & $\begin{array}{l}\text { Fwd } \\
\text { Rev }\end{array}$ & $\begin{array}{l}\text { AGCGAGATCACTTGGGAGGTGTTT } \\
\text { AAGTGTGTCACTCGAAACCAGGGA }\end{array}$ \\
\hline IL-18 & $\begin{array}{l}\text { SYBR } \\
\text { green }\end{array}$ & $\begin{array}{l}\text { Fwd } \\
\text { Rev }\end{array}$ & $\begin{array}{l}\text { ATGACATTGACAGGCCCAGAGGAA } \\
\text { GTTGCTCCAGTGGTTTGGCAGAAA }\end{array}$ \\
\hline IL-15 & $\begin{array}{l}\text { SYBR } \\
\text { green }\end{array}$ & $\begin{array}{l}\text { Fwd } \\
\text { Rev }\end{array}$ & $\begin{array}{l}\text { CGTTTATTGGAGCGCAGGACAAAG } \\
\text { CATGAGTTTCAGCAGCACCAGCAA }\end{array}$ \\
\hline CD208 & $\begin{array}{l}\text { SYBR } \\
\text { green }\end{array}$ & $\begin{array}{l}\text { Fwd } \\
\text { Rev }\end{array}$ & $\begin{array}{l}\text { CAACCCTGAGCCCACCGAGC } \\
\text { ATGCATGGCTTGCCTGCGGT }\end{array}$ \\
\hline IL-10 & $\begin{array}{l}\text { SYBR } \\
\text { green }\end{array}$ & $\begin{array}{l}\text { Fwd } \\
\text { Rev }\end{array}$ & $\begin{array}{l}\text { ACTCCGCACATCCTTCTCCACCA } \\
\text { TCATGGCGGTGGGCAACACC }\end{array}$ \\
\hline CCR6 & $\begin{array}{l}\text { SYBR } \\
\text { green }\end{array}$ & $\begin{array}{l}\text { Fwd } \\
\text { Rev }\end{array}$ & $\begin{array}{l}\text { ACGCTGCTGCGTGCCAAGAA } \\
\text { GCGCAGCGTTGTAGGGCAGA }\end{array}$ \\
\hline CD83 & Taqman & $\begin{array}{l}\text { Fwd } \\
\text { Rev } \\
\text { Probe }\end{array}$ & $\begin{array}{l}\text { GTGGCGGCATTGCTGATATT } \\
\text { CTTGTGGATACTTCTTACTCCTTTGCA } \\
\text { CACCATCAGCTATGTCATCC }\end{array}$ \\
\hline IL-1 $\beta 1$ & Taqman & $\begin{array}{l}\text { Fwd } \\
\text { Rev } \\
\text { Probe }\end{array}$ & $\begin{array}{l}\text { GCTGGAGAGTGCTGTGGAAGA } \\
\text { TGCTTCCCTCCTGCTCGTAG } \\
\text { TTGGAGTTGGAGTCGGCGCCC }\end{array}$ \\
\hline IFNa1 & Taqman & $\begin{array}{l}\text { Fwd } \\
\text { Rev } \\
\text { Probe }\end{array}$ & $\begin{array}{l}\text { ССTTTCCCTGCTGGACCA } \\
\text { TGTCTGTAAAGGGATGTTGGGAAAA } \\
\text { CTTTGTGATATCTCCTCCCATC }\end{array}$ \\
\hline $\mathrm{IFN} \gamma$ & Taqman & $\begin{array}{l}\text { Fwd } \\
\text { Rev } \\
\text { Probe }\end{array}$ & $\begin{array}{l}\text { AAGGGCTGTGATGTGTTTCTG } \\
\text { TGTACTGAGCGGCATTACTCC } \\
\text { TTGATGGGCTGGATGACTTTAGGA }\end{array}$ \\
\hline $\begin{array}{l}\text { Membrane } \\
\operatorname{lgM} \\
\text { (mlgM) }\end{array}$ & Taqman & $\begin{array}{l}\text { Fwd } \\
\text { Rev } \\
\text { Probe }\end{array}$ & $\begin{array}{l}\text { CCTACAAGAGGGAGACCGA } \\
\text { GATGAAGGTGAAGGCTGTTTT } \\
\text { TGACTGACTGTCCATGCAGCAACACC }\end{array}$ \\
\hline
\end{tabular}

(Continued)

\begin{tabular}{llll}
\hline $\begin{array}{l}\text { Secreted } \\
\text { lgM }\end{array}$ & Taqman & $\begin{array}{l}\text { Fwd } \\
\text { (slgM) }\end{array}$ & $\begin{array}{l}\text { CTACAAGAGGGAGACCGGAG } \\
\text { AGGGTCACCGTATTATCACTAGTTT }\end{array}$ \\
PAX5 & & Probe & TCCACAGCGTCCATCTGTCTTTC4 \\
& Taqman & $\begin{array}{l}\text { Fwd } \\
\text { Rev }\end{array}$ & CCACTGCCAGGTCGAGA \\
& & GTCAGCGAGGAGGTGGAGA \\
& & Probe & CCCCGGCTATCCACCACACG \\
EF1aB & Taqman & Fwd & TGCCCCTCCAGGATGTCTAC \\
& & Rev & CACGGCCCACAGGTACTG \\
& & Probe & AAATCGGCGTATTGG
\end{tabular}

\section{CONFOCAL MICROSCOPY}

Head kidney cells from fish injected with Ova-FITC and CpGCy5 attached to $15 \mathrm{~mm}$ coverslips were washed, with PBS and fixed for $15 \mathrm{~min}$ with $4 \%$ formaldehyde. Following permeabilization using $0.3 \%$ Triton $\mathrm{X}-100$ for $15 \mathrm{~min}$ at room temperature and blocking in PBS, 5\% FBS for $30 \mathrm{~min}$, the cells were incubated consecutively with 1:2000 dilution of MHCII $\beta$ antiserum and a secondary Alexa546-conjugated antibody. The coverslips were mounted in glycerol, $1 \%$ DABCO. Images were collected with a Zeiss Axiovert 200 microscope with a $40 \times$, Apochroma objective, equipped with an LSM510-META confocal module using the LSM5 software version 3.2 (Carl Zeiss Inc.).

For in vitro Ag uptake and sub-cellular localization, adherent HK mononuclear phagocytes were isolated as previously described (Iliev et al., 2010). To visualize endolysosomes, cells cultured in Lab-Tek ${ }^{\mathrm{TM}}$ Chambered Coverglass slides (Nunc) were incubated with $1 \mu \mathrm{M}$ LysoSensor ${ }^{\mathrm{TM}}$ Green DND-189 (Life technologies) for $30 \mathrm{~min}$, washed and incubated in L-15, 5\% FBS with $10 \mu \mathrm{g} / \mathrm{ml}$ of Ova-Alexa647. Images of live cells were taken as described above.

\section{WESTERN BLOT}

Samples from sorted cells $\left(1 \times 10^{5}\right.$ per sample $)$ were pelleted ( $1500 \mathrm{~g}, 5 \mathrm{~min}$ ), lyzed in LDS sample buffer (Invitrogen) and run on NuPAGE Novex Bis-Tris $12 \%$ gel (Invitrogen). The proteins were transferred to PVDF membranes, blocked with 5\% dry milk and incubated consecutively with a 1:1000 dilution of LC3 antibody and a 1:10000 dilution of a goat anti-rabbit-horseradish peroxidase antibody. Stripping of the membranes was performed in $0.2 \mathrm{M} \mathrm{NaOH}$ for $10 \mathrm{~min}$ followed by washing, blocking, and reprobing with 1:1000 dilution of an eEF2 polyclonal antibody.

\section{MORPHOLOGY OF SORTED HK CELLS - TRANSMISSION ELECTRON MICROSCOPY ANALYSIS}

Sorted HK subpopulations were pelleted in a microcentrifuge $(1500 \mathrm{~g}, 5 \mathrm{~min})$ and fixed in $8 \%$ formaldehyde. Cells were washed in $0.1 \%$ cacodylate buffer ( $\mathrm{pH} 7.2$ ), post fixed in mixture of $2 \%$ osmium tetroxide $1.5 \%$ potassium ferrocyanide in $0.1 \%$ cacodylate for $30 \mathrm{~min}$. Staining was performed with $1 \%$ tannic acid and $1 \%$ uranyl acetate, followed by dehydration in a graded series of ethanol $(70 \%, 90 \%, 96 \%, 2 \times 100 \%)$. The cells were treated with acetonitrile as an intermediate step before infiltration with an Epon substitute (AGAR 100 resin, Agar Scientific, Stansted, 
England) and polymerized at $60{ }^{\circ} \mathrm{C}$ overnight. Ultrathin sections $(70 \mathrm{~nm})$ were made using a Leica Ultracut S Ultramicrotome (Vienna, Austria) with a Diatome diamond knife (Biel, Switzerland). The sections were mounted on carbon coated formvar films on copper grids and contrasted with 5\% uranyl acetate for $8 \mathrm{~min}$ and Reynolds lead citrate for $5 \mathrm{~min}$. Micrographs were taken on a Jeol 1010 JSM (Tokyo, Japan) with a Morada 11 Mpixels digital camera (Olympus).

\section{IMMUNOLABELING FOR ELECTRON MICROSCOPY}

Sorted HK subpopulations were pelleted in a microcentrifuge ( $1500 \mathrm{~g}, 5 \mathrm{~min}$ ) and fixed in 4\% formaldehyde in $200 \mathrm{mM}$ HEPES buffer, $\mathrm{pH} 7.5$, for $1 \mathrm{~h}$. The samples were prepared for immunolabeling according to standard methods. Ultrathin cryosections cut on a Leica EMUC6 Ultramicrotome with an Ultracut S in a Leica FCS cryochamber using a diamond knife (Diatome Ltd., Bienne, Switzerland) and mounted on Formvar-coated EMgrids. Immunocytochemical labeling was performed as described (Tokuyasu, 1986; Webster and Webster, 2007). The Anti-LC3 antibody was used at 1:1000 dilution and was detected by protein A-gold complexes. The dried sections were examined in a JEOL JEM 1010 transmission electron microscope (JEOL, Tokyo, Japan) operating at $80 \mathrm{kV}$. Control experiments were routinely included in parallel by omission of the primary antibodies.

\section{DATA ANALYSIS}

Data was analyzed with one-way and two-way ANOVA, as indicated, followed by Tukey post-tests. Statistical analyses were performed using the GraphPad Prism6 software. The value of $p<0.05$ was considered to be significant. Only groups with $n>3$ were included in the analysis.

\section{RESULTS}

\section{SOLUBLE ANTIGEN AND CpGs INJECTED IN THE ABDOMINAL CAVITY OF ATLANTIC SALMON ACCUMULATE PREDOMINATELY IN HK MHCII+ CELLS}

To analyze the Ova distribution in vivo, salmon $(\sim 100 \mathrm{~g})$ were injected intra-abdominally with $500 \mu \mathrm{g}$ of Ova-FITC or with $500 \mu \mathrm{g}$ of Ova-FITC mixed with $50 \mu \mathrm{g}$ of CpG-Cy5. Control fish were injected with the same volume $(100 \mu \mathrm{l})$ of PBS. HK and spleen leukocytes were isolated after 1,5, and 14 days and following staining for surface MHCII and IgM were analyzed using flow cytometry. The results shown in Figure 1A demonstrate that Ova and CpGs are detected in both spleen and HK cells 1 day post injection. The percentage of Ova+ and $\mathrm{CpG}+$ cells in $\mathrm{HK}$ and spleen were approximately equal at this time point $(\sim 2 \%$ in both organs). Since, considerably more leukocytes were isolated from $\mathrm{HK}$, the absolute number of Ova + cells was greater in this organ as compared to spleen. Although there was relatively more $\mathrm{CpG}+$ than Ova+ cells in $\mathrm{HK}$, there was a relatively good correlation in the uptake of the two substrates. It seems that the higher percentage of $\mathrm{CpG}+$ cells might be due to a higher intensity of the CpG-Cy5 fluorescence as compared to that emitted by Ova-FITC. Confocal microscopy analysis revealed that Ova-FITC and CpGCy5 colocalized in intracellular vesicles in MHCII+ cells from HK harvested $24 \mathrm{~h}$ post injection (Figure 1B). These cells had a macrophage-like morphology as revealed by the presence of long and branching pseudopodia.
The dot plots presented in Figure 1C show cells isolated 1 day post injection. Most of the Ova + and $\mathrm{CpG}+\mathrm{HK}$ cells expressed surface MHCII but not IgM. In contrast, in spleen an approximately equal percentage of the Ova + and the $\mathrm{CpG}+$ cells were MHCII- and MHCII+, and most of these were IgM-. The histograms in Figure 1D show the average percentage of the Ova+ cells in the Ova-only and the Ova/CpG-injected groups. The results demonstrate that while on day one the percentages of Ova+ cells in HK and spleen are comparable, on day 5 and day 14 the values in spleen decline whereas those in HK remain high for up to 14 days. The data also show that in $\mathrm{HK}$ at all tested time points most of the Ova+ cells are MHCII+. The addition of $50 \mu \mathrm{g} \mathrm{CpGs}$ to the Ova, a dose that previously has been shown to upregulate expression of immune genes in both HK and spleen (Strandskog et al., 2008), did not seem to affect the accumulation of Ova+ cells in neither HK nor spleen. The experimental setup included five fish per group/time point; however, due to the large number of samples, for some of the groups only two samples could be analyzed which makes statistical analysis unreliable.

\section{IN VITRO UPTAKE OF DEXTRAN, Ova, AND CpG ODNs BY HK LEUKOCYTES}

The potential of HK leukocytes to take up Ova and CpGs was further analyzed in vitro. The results shown in Figure 2A demonstrate that, except for the higher percentage of leukocytes that were able to accumulate significant amounts of Ova (ranging between 9 and 20\%), the in vitro experiment produced similar results as the in vivo trial. Namely, the substrate was accumulated at high levels exclusively by MHCII+ cells. The group of cells which were highly stained for surface MHCII and most of the IgM+ cells did not endocytose significant amounts of Ova. In contrast, almost all of the HK leukocytes accumulated large amounts of CpG ODNs (Figure 2B). Distinct cell populations endocytosed different levels of CpG ODNs. Of note, the cells with high capacity to endocytose Ova accumulated considerably more $\mathrm{CpG}$ ODNs as compared to the other cells types.

In order to investigate if the Ova-FITC+ cells detected in $\mathrm{HK}$ during the in vivo trial were still able to endocytose soluble Ag, HK cells from Ova-FITC-injected fish were incubated in vitro in the presence of $10 \mu \mathrm{g} / \mathrm{ml}$ of Ova-Alexa647 and the uptake of the in vivo and the in vitro endocytosed substrates were detected separately through the green and the far-red channels of the flow cytometer. The results are shown in Figure $\mathbf{2 C}$ and demonstrate that the Ova-FITC+ cells retained high capacity to endocytose the substrate in vitro. Due to the overlap between the emission spectra of Cy5 and the Alexa647 cells from fish injected with CpGCy5 ODNs could not be included in this experiment. Instead, dextran-Cascade blue conjugate was used to test the capacity of the CpG-Cy5+ cells found in HK during the in vivo trial to endocytose soluble substrate. As demonstrated in Figure 2D, the CpG+ cells had ability to endocytose high amounts of dextran in vitro, suggesting that these are still immature APCs.

\section{ADHERENT HK MONONUCLEAR PHAGOCYTES PROCESS Ova AND ACCUMULATE THE Ag WITHIN ACIDIFIED ENDOCYTIC COMPARTMENTS}

Ovalbumin-DQ is a self-quenched conjugate of Ova that exhibits bright green fluorescence upon proteolytic degradation. In order 


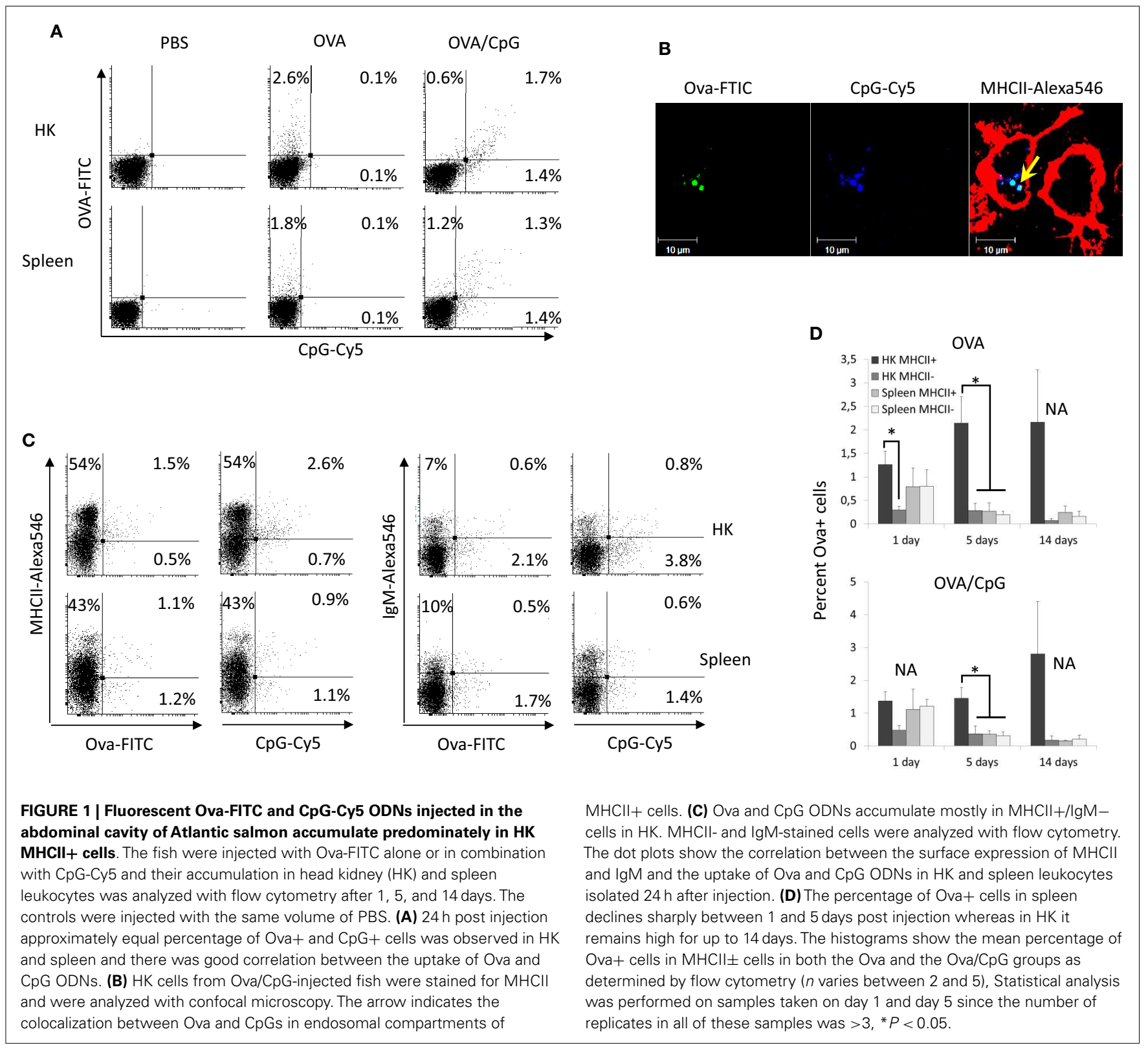

to investigate the ability of salmon HK APCs to process Ag, HK cells were incubated with Ova-DQ for $4 \mathrm{~h}$ followed by flow analysis. Non-adherent and adherent cells were harvested and analyzed separately after staining for surface MHCII. The results presented in Figure 3A show that unlike non-adherent $\mathrm{MHCII}++$ granulocytes, adherent HK MHCII+ cells possess ability to effectively take up and process Ova.

The intracellular distribution of Ova was examined in adherent HK mononuclear phagocytes in which late endosomes and lysosomes were labeled with LysoSensor. As shown in Figure 3B, the endocytosed Ova was detectable in acidic vesicles within $1 \mathrm{~h}$ after addition of the Ag to the cell culture medium. The accumulation of Ova in LysoSensor+ vesicles was more pronounced after $24 \mathrm{~h}$ of incubation.

\section{DISTINCT HK CELL POPULATIONS ARE FOUND BASED ON SURFACE MHCII AND IgM EXPRESSION, OVA UPTAKE, AND MORPHOLOGY}

To further characterize the different HK leukocyte subpopulations cells were sorted using a FACSAria instrument according to their ability to endocytose Ova and the surface MHCII and IgM expression. The sorted samples were then analyzed using microscopy and RT-PCR.

The pre-sort dot plots in Figure 4 show the setup of the gates. Unlike the Ova-/Ig + cells which had typical lymphocyte morphology the Ova+/IgM+ cells were larger and granular and were excluded from the analysis as they may also have included macrophages which had bound IgM through their Fc receptors. As shown in the post-sort dot plots, nearly all of the IgM+ cells were also positive for surface MHCII. The post-sort analysis indicated 
A
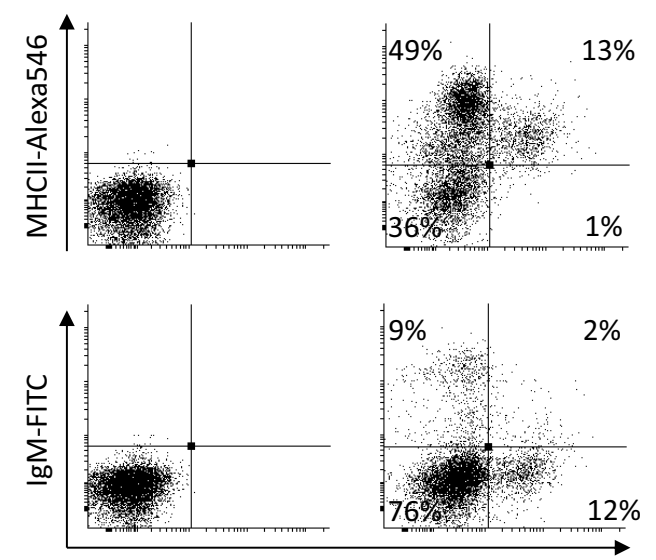

Ova-Alexa647 (in vitro uptake)
B
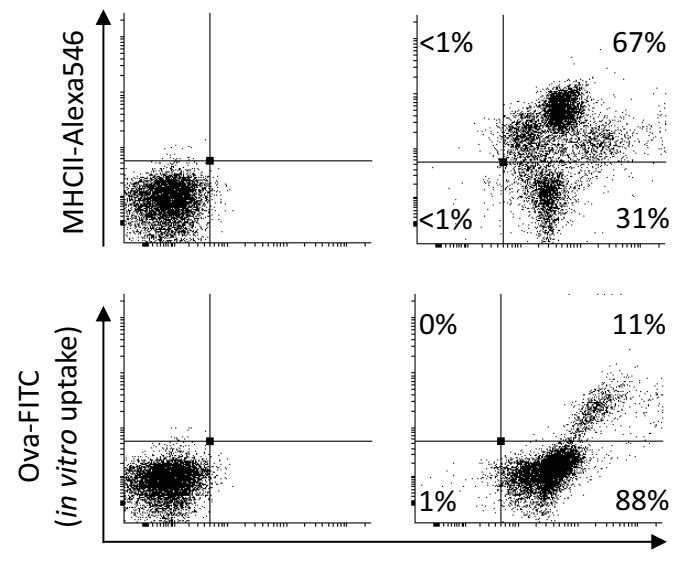

CpG-Cy5 (in vitro uptake)
C

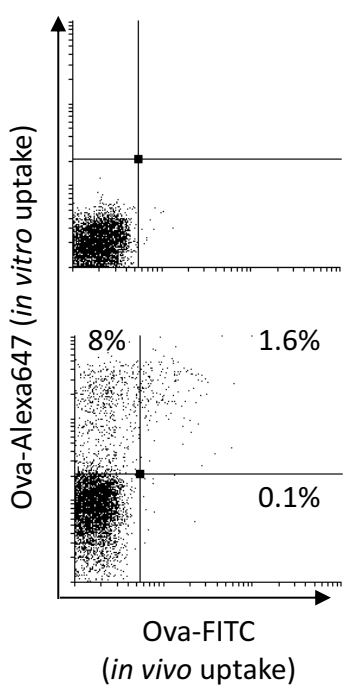

D

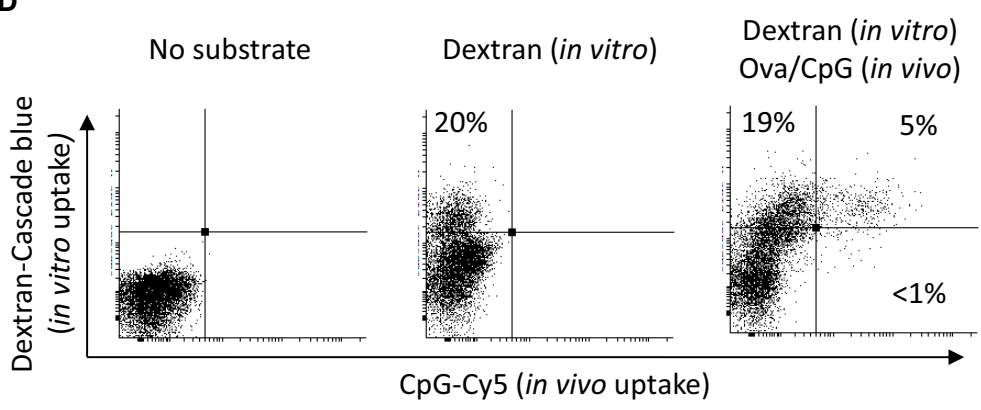

FIGURE 2 | In vitro uptake of Ova CpGs and dextran by HK leukocytes

(A) the vast majority of the cells that take up Ova in vitro are $\mathrm{MHCll}+/ \mathrm{lgM}-$. HK cells were incubated in vitro with $10 \mu \mathrm{g} / \mathrm{ml}$ of Ova-FITC for $1 \mathrm{~h}$ prior to staining for surface $\mathrm{MHCll}$ and IgM and flow analysis. (B) In contrast with Ova, almost all of the HK leukocytes were able to take up significant levels of $\mathrm{CpG}$ ODNs. The cells that were able to endocytose Ova accumulated considerably more CpG ODNs as compared to the other cells. The HK leukocytes were incubated in vitro in the presence of Ova and $2 \mu \mathrm{M} \mathrm{CpG-Cy5}$ ODNs for $1 \mathrm{~h}$ prior to staining and flow analysis. Both in $(\mathbf{A}, \mathbf{B})$, the left dot plots show the non-stained controls. (C) The
Ova-FITC+ cells found in HK after intra-abdominal injection endocytose Ova in vitro. The cells were incubated with $10 \mu \mathrm{g} / \mathrm{ml}$ of Ova-Alexa647 and the in vivo and the in vitro uptake of Ova was analyzed in the green and the far-red channels, respectively. The upper dot plot is a control with cells from PBS-injected fish, incubated without Ova-Alexa647. (D) CpG+ APCs found in the HK following an intra-abdominal administration exhibit high endocytic capacity in vitro. The cells were cultured in the presence of $150 \mu \mathrm{g} / \mathrm{ml}$ of dextran-Cascade blue conjugate prior to flow cytometry analysis. Representative plots from at least two experiments with cells from two individuals are shown. that the purity of the sorted cells was at least $90 \%$ which was deemed high enough for further analyses. The side (SSC) versus the forward scatter (FSC) plots are included to show the morphology of the sorted cells. The MHCII-/Ig-/Ova- group included cells with variable size (FCS parameter) and low granularity (SSC). The MHCII+/Ig-/Ova+ group contained large cells with higher, but relatively modest granularity. The majority of the MHCII+/Ig+/Ova- cells were small and weakly granular whereas the $\mathrm{MHCII}++/ \mathrm{Ig}-/ \mathrm{Ova}-$ were large and highly granular, indicating that this group is composed of granulocytes.
Light microscopy examination of May Grünwald-Giemsa stained sorted cells (Figure 5A), showed that the cells sorted in the MHCII-/Ova- gate displayed typical lymphocytic morphology with round nuclei, low cytoplasm versus nucleus ratio and intensely stained cytoplasm. The cells sorted in the MHCII+ gates had high cytoplasm/nucleus ratio. The Ova+ cells had mononuclear morphology with oval to bean-shaped nuclei and with a relatively densely stained cytoplasm. The $\mathrm{MHCII}++/ \mathrm{Ova}-$ granulocytes had polymorphic nuclei with finely granulated and a relatively weakly stained cytoplasm indicating that these are 

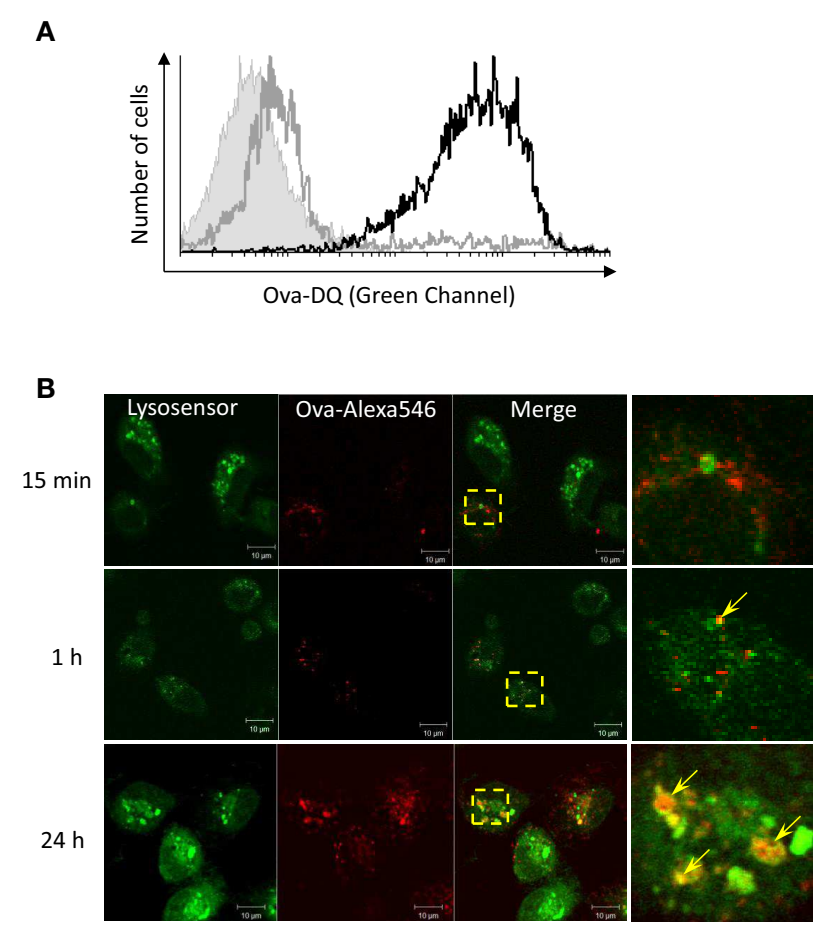

FIGURE 3 | Adherent HK mononuclear phagocytes hydrolyze Ova and accumulate the $\mathbf{A g}$ within acidified endocytic compartments. (A) Head kidney leukocytes were incubated for $4 \mathrm{~h}$ with $5 \mu \mathrm{g} / \mathrm{ml}$ of Ova-DQ.

Non-adherent and adherent cells were harvested and analyzed separately with flow cytometry. Gray contour - non-adherent $\mathrm{MHCll}++$ granulocytes, black contour - adherent $\mathrm{MHCll}+$ cells. The filled contour shows a non-stained control. Ova-DQ fluorescence is detected in the green channel. Similar results were obtained with cells from two individuals. (B) Adherent head kidney mononuclear phagocytes attached to chambered coverglass slides were stained with LysoSensor Green (pKa 5.2) and incubated with Ova-Alexa647 for the indicated periods prior to live imaging using a confocal microscope. The arrows in the magnified overlap regions indicate accumulation of Ova within late endosome/lysosome compartments.

polymorphonuclear granulocytes. The ultrastructure of the sorted cells was examined with transmission electron microscopy (TEM) (Figure 5B). Except for the cell nuclei, a few small mitochondria and abundance of free ribosomes, no other clear structures could be observed in the MHCII-/Ova- cells. The MHCII+/Ova+ cells had long pseudopodia which upon fusion form macropinosomes (MPS) indicating that these cells perform macropinocytosis constitutively. The cells also had abundant mitochondria, extensive rough endoplasmic reticulum and, some of them, melanin granules. In addition, in some cells, early/sorting endosomes (E/SE) could be observed (magnified inset). Typically, these appear as vesicles with attached tubules into which the receptors such as those involved in the endocytosis of mannosylated substrates (i.e., the mannose receptor) are recycled toward the cells surface (Wileman et al., 1985; Jovic et al., 2010). Endocytosed proteins remain in the body of the E/SE and are transported toward degradation by lysosomal enzymes. The MHCII++/Ova- granulocytes contained many small and moderately sized vesicles (up to $400 \mathrm{~nm}$ ) with varying density and round to elongated shape. Internal membranes with lamellar or vesicular shape were visible in some of these lysosome-like vesicles. Interestingly, one of the observed vesicles appeared to be in a process of microautophagy as suggested by the presence of an arm-like extension surrounding parts of the neighboring cytoplasm. No large pseudopodia, MPS, E/SE, and melanin granules were observed in these cells. Also, compared to the Ova+ cells these polymorphonuclear granulocytes contained fewer mitochondria and less RER.

\section{DIFFERENT MHCII+ HK LEUKOCYTE SUBPOPULATIONS SHOW DISTINCT GENE EXPRESSION PROFILES}

RNA samples from sorted cells were used to analyze gene expression in resting and in activated HK leukocytes subpopulations. CpG stimulation in higher vertebrate species directly activates DCs, macrophages, and B-cells, leading to upregulation of costimulatory molecules and proinflammatory cytokines and an increased capacity for antigen processing and presentation (Hartmann et al., 1999). Similarly, in Atlantic salmon, in vitro stimulation of adherent mononuclear phagocytes with CpGs for $24 \mathrm{~h}$ induced expression of proinflammatory cytokines and marker genes for mature APCs (Iliev et al., 2010). In the current study, the whole HK leukocyte population was stimulated with CpG-B for $24 \mathrm{~h}$ prior to sorting and gene expression analysis using RT-PCR. Among the leukocyte marker genes, the basal level of CD83, CD86, and B7-H1 was highest in the Ova+ cells (Figure 6A). However, the CpG treatment upregulated CD83 and CD40 most highly in the MHCII++/IgM-/Ova- cells. The expression of CD208 and IFN- $\gamma$ was highest in IgM+ cells.

Interestingly, there was a contrast in the expression patterns of the proinflammatory cytokines TNF2 and IL-1 $\beta 1$. The former was most highly expressed in the Ova + cells whereas both the basal and the CpG-upregulated IL- $1 \beta 1$ mRNA level were highest the MHCII++/Ig-/Ova- cells. The expression of the two cytokines was further confirmed in sorted cells from two additional fish, The TNF2 expression in non-stimulated MHCII- cells from fish 3 and fish 4 was not detectable making it impossible to calculate the "fold difference" expression of the cytokine in these samples. Nevertheless, as indicated by the ratio between the threshold cycle $(\mathrm{Ct})$ values of the housekeeping gene and the cytokine, the $\mathrm{MHCII}+/ \mathrm{Ova}+$ cells consistently expressed the highest levels of TNF2 mRNA, whereas the MHCII++/Ova- cells gave the highest levels of IL-1 $\beta 1$ mRNA when compared with other cell types from the same individual (Figure 6B). The MHCII++ granulocytes also expressed highest levels of IL1R1 and IL1R2 mRNA. On the other hand, the TNF receptor family members decoy receptor 3 (DCR3) and osteoprotegerin (OPG) were most highly upregulated in the Ova+ cells. In contrast with IL-1 $\beta 1$ and TNF2, the anti-inflammatory cytokine IL-10 was approximately equally upregulated by CpGs in Ova+ and $\mathrm{MHCII}++/ \operatorname{IgM}-/$ Ova - cells. IL-18 belongs to the IL-1 cytokine family and its expression was relatively high in Ova + and in $\mathrm{MHCII}++/ \operatorname{IgM}-/ \mathrm{Ova}-$; however, unlike IL1B1, it was downregulated by the CpGs. Like IL18, IL-15 was not upregulated by CpGs and its expression was weakest in IgM+ cells. The CCR6 mRNA was detected only in the MHCII-/IgM-/Ova - and in the MHCII+/Ova+ cells and in the latter, the CpG treatment downregulated its mRNA to undetectable level. 


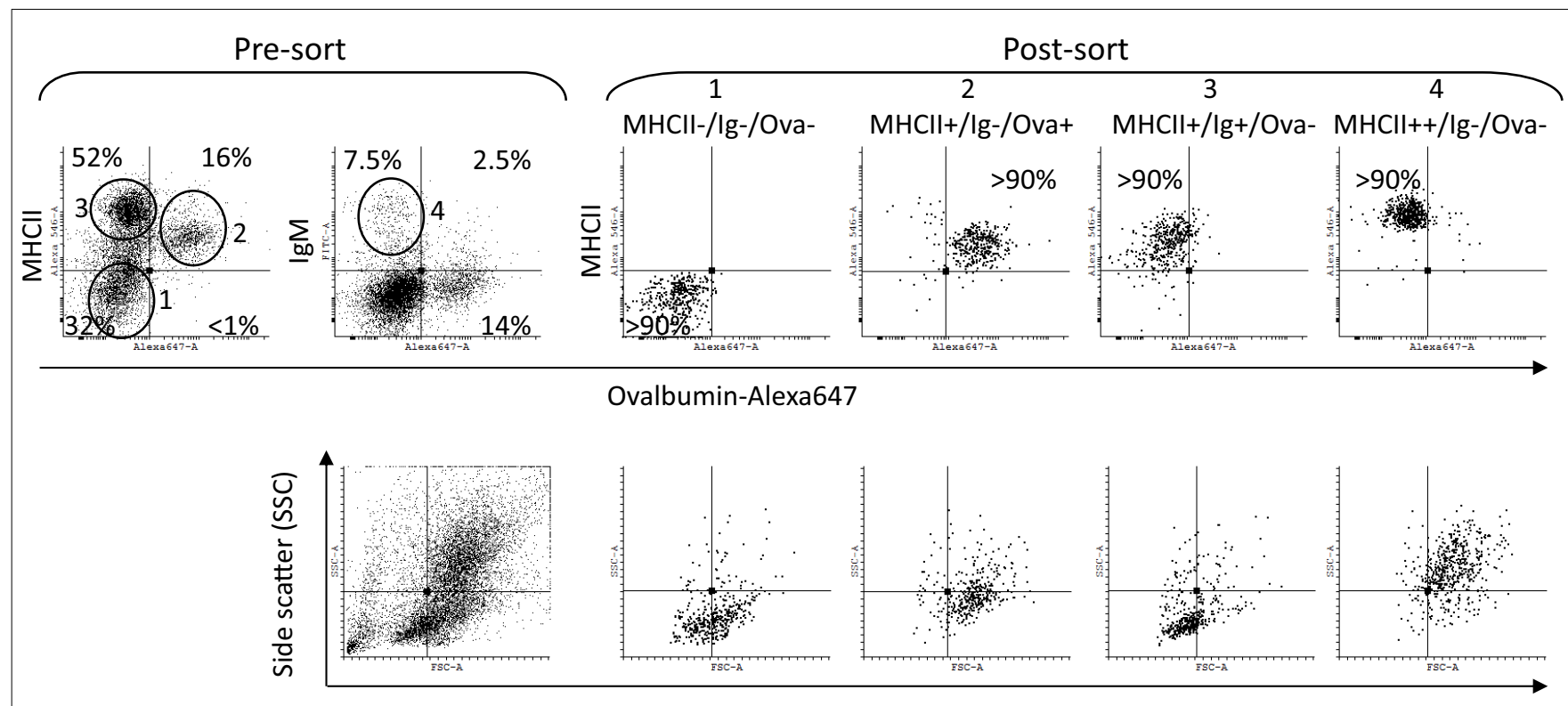

Forward scatter (FSC)

FIGURE 4 | Sorting of HK cells according to surface MHCII and IgM expression and Ova uptake. The cells were incubated in vitro for $1 \mathrm{~h}$ with Ova-Alexa647 $(10 \mu \mathrm{g} / \mathrm{ml})$ double stained for surface $\mathrm{MHCll}$ and IgM and sorted using a FACSAria instrument. The pre-sort dot plots show the sorting gates setup. The post-sort analysis confirmed the sorting quality (>90\%) for all of the populations and the morphology of the sorted cells was determined by the FSC (cell size) and the SSC (cell granularity) parameters, shown in the lower dot plots.
PAX5 is a transcription factor involved in the early stages of B-cell development but its expression is suppressed during the late stages of plasma cell differentiation (Barberis et al., 1990) and a similar expression pattern for PAX5 has also been demonstrated in rainbow trout (Zwollo et al., 2005). In sorted cells, PAX5 was most highly expressed in the MHCII-/IgM-/Ova- and the IgM+ cells and the CpG stimulation downregulated its expression. The expression of the mIgM in resting cells paralleled that of PAX5 and the sIgM mRNA was induced by CpGs in IgM+ cells.

\section{AUTOPHAGY FLUX ANALYSIS}

Autophagy is a phylogenetically conserved mechanism through which eukaryotic cells degrade cytoplasmic material and whole organelles (Mizushima, 2007). IL-1 $\beta$ does not have a signal peptide and therefore it cannot be exported through the classical secretory pathway. It has recently been found that autophagy is implicated in the secretion of this cytokine (Klionsky et al., 2008; Dupont et al., 2011). The autophagy flux can be evaluated through Western blot (WB) analysis of the conversion of LC3B-I into LC3B-II, the latter of which migrates faster on PAGE. One potential problem with this analysis is the degradation of LC3BII once the autophagosomes (AP) fuse with lysosomes (Klionsky et al., 2008). To block the lysosomal proteolysis and allow of LC3B-II to accumulate, CHQ was added to the cells $24 \mathrm{~h}$ prior to sorting and WB analysis using a commercial antibody. The representative image shown in Figure 7A demonstrates that following treatment with $\mathrm{CHQ}$, the $\mathrm{MHCII}++/ \mathrm{Ova}-$ granulocytes accumulate higher amount of LC3B-II. However, TEM analysis showed that double-membrane vesicles which surround parts of the cytoplasm and appear to be AP could be observed only in the MHCII+/Ova+ cells but not in the MHCII++/Ova- leukocytes incubated with CHQ (Figure 7B). Nevertheless, the CHQ treatment increased the density of the vesicles found in the latter cells and immunogold staining/TEM showed that these vesicles were positive for LC3 suggesting that these might be involved in autophagy or autophagy-related processes (Figure 7C).

\section{DISCUSSION}

A major objective of the current paper has been to characterize salmon APCs in regards to their ability to take up soluble antigen and to migrate toward secondary lymphoid organs. The results demonstrate that there is a specific population of MHCII+ cells which are able to endocytose Ag in the periphery and which over a period of up to 14 days following the $\mathrm{Ag}$ administration in the abdominal cavity, accumulate predominately in salmon $\mathrm{HK}$, but not in spleen. In vitro, these adherent cells accumulated Ova within late endosomes/lysosomes and were able to process Ova indicating that they are professional APCs.

The high capacity of APCs such as DCs to endocytose soluble Ags relies on receptor-mediated endocytosis and macropinocytosis (Sallusto et al., 1995). The former mechanism is mediated by receptors such as the mannose receptor expressed by macrophages and DCs and is necessary for the high-efficiency endocytosis of glycoproteins found on the surface of viruses, bacteria, and experimental substrates such as Ova and dextran (Sallusto et al., 1995; Burgdorf et al., 2006). On the other hand, the macropinocytosis is a process implicated in non-specific uptake of large amounts of extracellular fluid through membrane invaginations and lamellipodia (Lim and Gleeson, 2011). Both processes are downregulated upon activation of immature DCs by PAMPs 


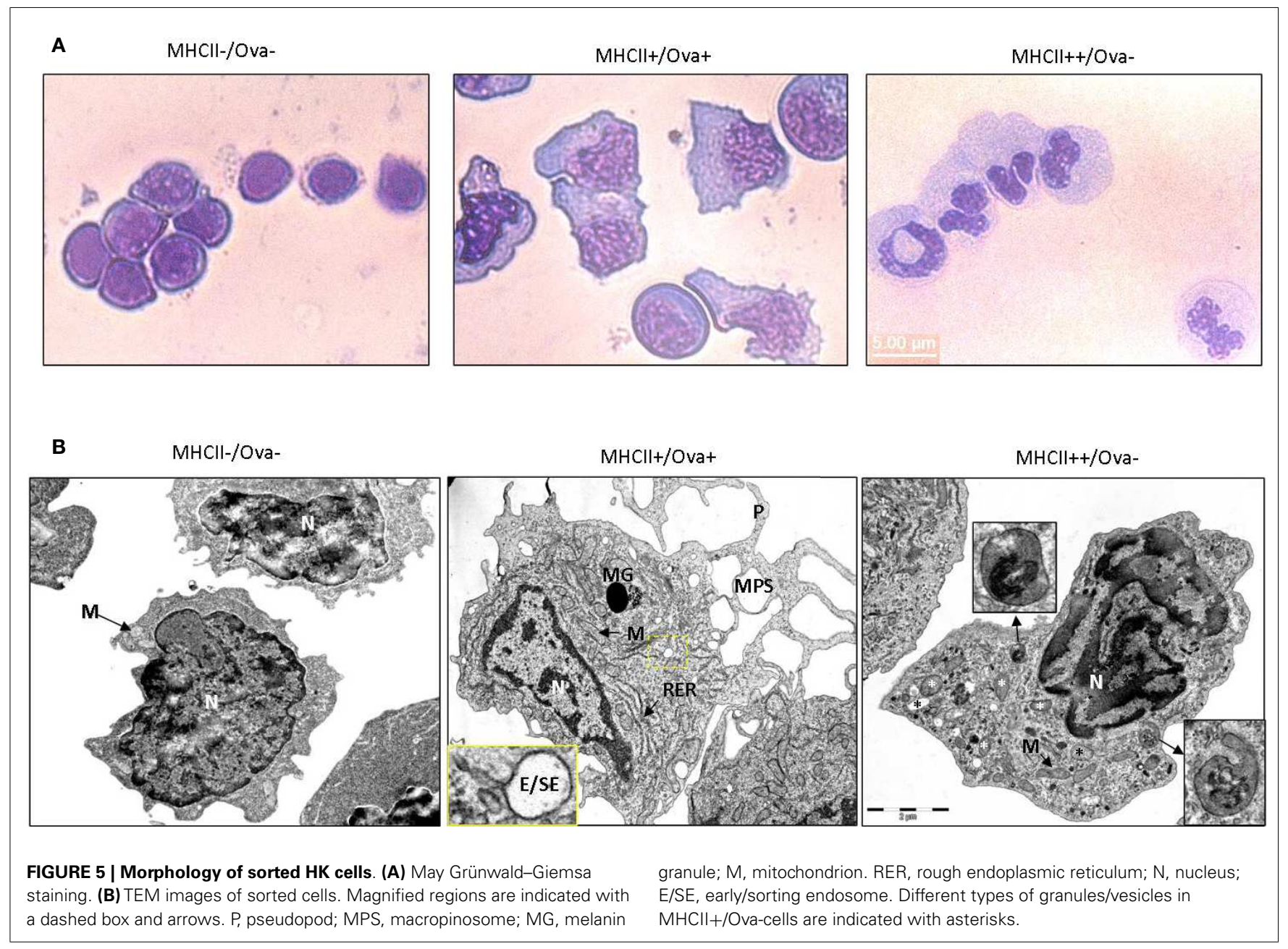

or cytokines (Sallusto et al., 1995). In mammals, synthetic CpG ODNs are known to be potent vaccine adjuvants due to their potential to induce maturation of DCs (Askew et al., 2000; Klinman, 2003). This process is typically manifested by upregulation of surface MHCII and co-stimulatory molecules and downregulation of the Ag-uptake capacity trough inhibition of the receptormediated endocytosis and the macropinocytosis (Sallusto et al., 1995). It has previously been shown that in vitro stimulation of salmon mononuclear phagocytes with CpG-B upregulates a large array of immune genes, including markers for mature APCs, and it lowers the capacity of these cells to take up dextran and Ova (Iliev et al., 2010; Lagos et al., 2012). In the current study, injection with CpG ODNs did not seem to affect the migration of cells toward HK and spleen since the number of Ova+ cells in both organs did not differ significantly between the Ova and the Ova CpG-injected groups. Furthermore, the $\mathrm{CpG}$ treatment did not detectably upregulate the surface expression of MHCII and the $\mathrm{HK} \mathrm{CpG}+$ cells isolated following in vivo treatment were still able to endocytose significant amounts of dextran suggesting that these are still immature APCs. The CpG dose administered in vivo in the current study has been previously shown to induce expression of immune genes in salmon
HK and spleen including IFN- $\gamma$ and IL1 $\beta$ (Strandskog et al., 2008). However, the current data suggests that it may not be potent enough to trigger maturation of salmon APCs under these conditions.

While not very likely, it cannot be excluded that the substrates injected intra-abdominally may have diffused throughout the organism at high enough concentrations to be accumulated at detectable levels in $\mathrm{HK}$ and spleen cells in situ. The in vitro experiments indicated that this was not the case since a significantly higher percentage of HK leukocytes were able to accumulate high amounts of Ova and CpG ODNs in vitro as compared to the in vivo trial. This indicates that cells had taken up the substrate in the periphery prior to migrating toward the HK.

A previous study in which the expression of surface MHCII was analyzed in salmon HK and spleen leukocytes identified a population of granular cells which expressed relatively high levels of surface MHCII but had a low capacity to endocytose dextran and Ova (Iliev et al., 2011; Lagos et al., 2012). In the current study, the morphology of sorted cells, examined using May Grünwald-Giemsa staining and TEM indicate that these cells are most likely polymorphonuclear granulocytes. The relatively high MHCII expression on their surface and the upregulation of APC 


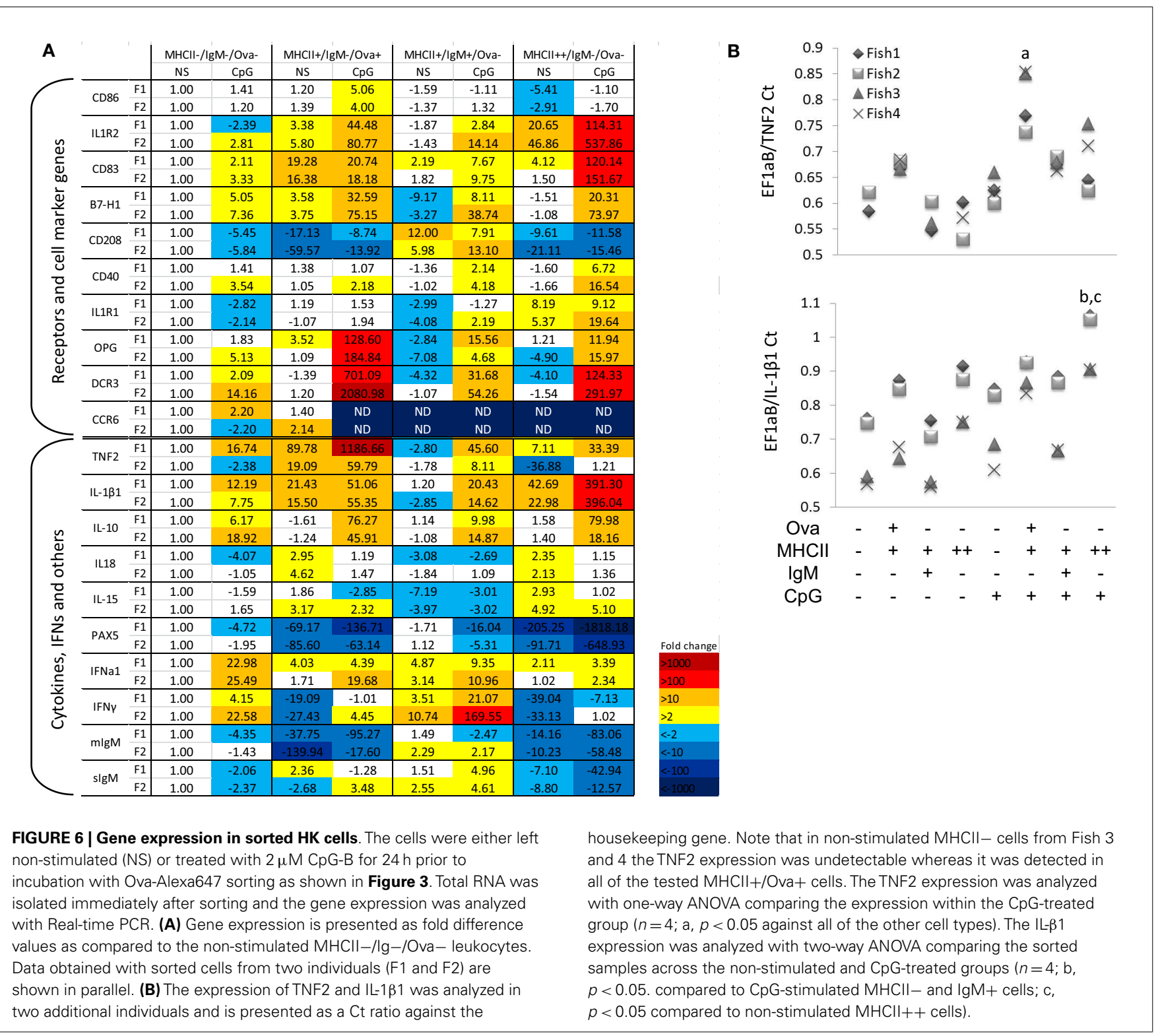

marker genes including CD83, CD40, and B7-H1 is somewhat surprising since in mammals granulocytes are typically, short-lived effector cells involved in clearance of bacterial and parasitic infections (Kobayashi et al., 2005). Nevertheless, studies have demonstrated that under specific conditions, murine neutrophils may upregulate MHCII and they can effectively present exogenous Ag to T-cells (Abi Abdallah et al., 2011). In addition, high expression of MHCII has been detected in seabream acidophilic granulocytes (functionally analogous to mammalian neutrophils) (Cuesta et al., 2006) and in zebrafish eosinophils (Wittamer et al., 2011) indicating that fish granulocytes may, potentially, be involved in antigen presentation.

In addition to exogenous substrate endocytosis, an alternative mechanism for delivery of antigens to intracellular MHCII compartments is autophagy. This is a process through which cytoplasmic constituents are delivered to lysosomes for degradation and it has been implicated in induction of immune response against intracellular parasites and in maintaining tolerance to autoantigens (Vyas et al., 2008; Klein et al., 2010). The relatively high level of conversion of LC3-II, in MHCII++ HK granulocytes indicates that these cells actively perform autophagy which may, potentially, be a source of peptides to be presented on MHCII molecules.

The CHQ treatment induced the appearance of typical AP in the MHCII+/Ova+ cell whereas in the MHCII++/Ova- granulocytes such double-membrane structures containing cytoplasmic material could not be observed. Nevertheless, the presence of LC3 and heterogeneous material in electron-dense vesicles found in the granulocytes indicates that these might be involved in autophagy, possibly microautophagy, or related processes such as LC3-associated phagocytosis. In this regard, LC3-II has been found in secretory granules of mast cells and autophagy has been 
A

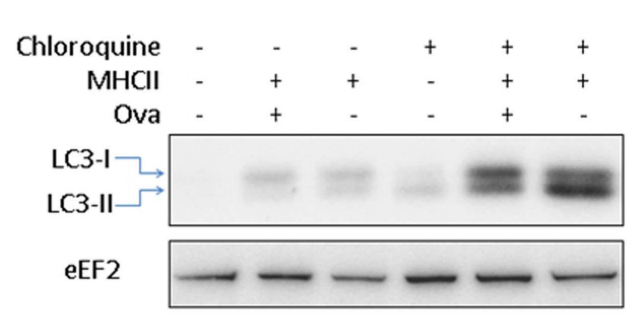

B

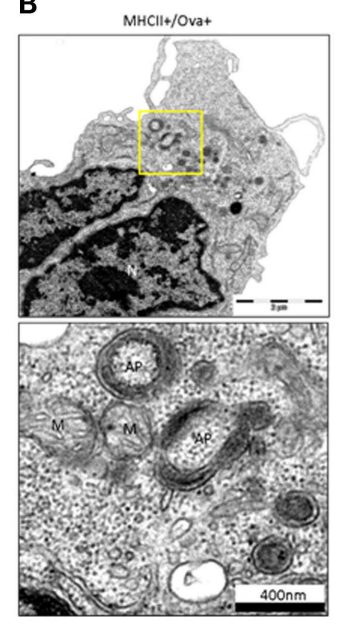

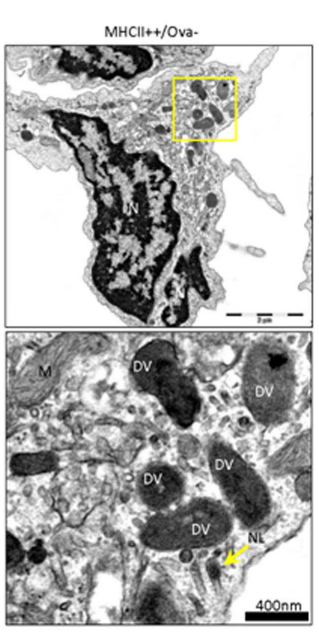

FIGURE 7 | Autophagy flux analysis in sorted HK subpopulations. (A) HK cell were incubated with $\mathrm{CHQ}(5 \mu \mathrm{g} / \mathrm{ml})$ for $24 \mathrm{~h}$ and sorted as described above. Protein samples from sorted cells were analyzed with WB using an antibody against LC3B. The histogram shows the intensity of the normalized LC3-II bands. eEF2 was used as a loading control. Similar results were obtained with samples from two individuals. (B) $\mathrm{CHO}$ treatment induces formation of autophagosomes (AP) in MHCll+/Ova+ cells. Prior to sorting, the cells were treated with $\mathrm{CHO}$ as in (A). The autophagosomes appear as shown to be crucial for mast cell degranulation (Ushio et al., 2011). Elucidating the involvement of autophagy in the function of the fish immune system will be a subject for additional, more focused studies.

The high migratory potential of immature DCs is conferred by the expression of various chemokine receptors. One of them, CCR6, is critical for the migration of murine DCs toward secondary lymphoid organs and upon maturation it is downregulated (Carramolino et al., 1999). Although, following CpG stimulation, the Ova+ cells did not upregulate surface expression of MHCII, the down regulation of CCR6 and the upregulation of CD86 indicate that they do have a potential to differentiate into mature APCs.

Interestingly, the upregulation of the proinflammatory cytokines TNF2 and IL-1 $\beta 1$ was cell type-dependent. While the former was most highly expressed in Ova+ cells, the latter was upregulated to the highest extent in the MHCII++/Ova- granulocytes. It could be argued that the upregulation of these cytokines might differ significantly based on the length of stimulation; however, it is notable that the level of expression of both cytokines in non-stimulated cells paralleled that in the CpG-stimulated

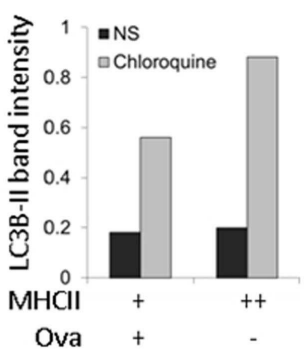

C

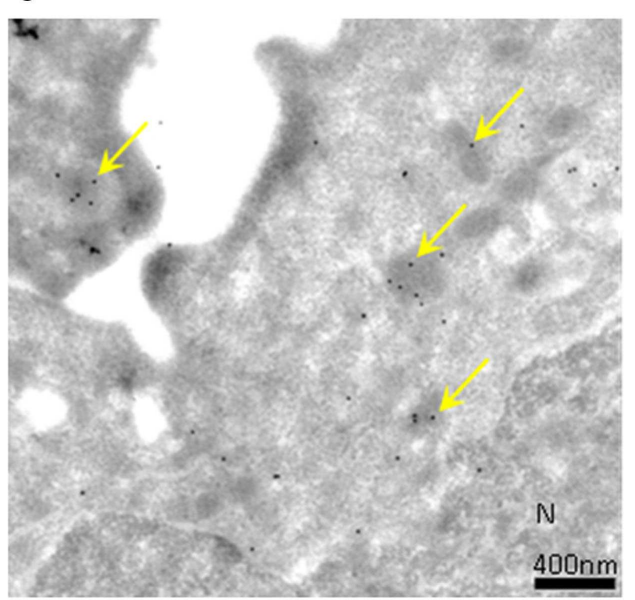

double-membrane vesicles which surround parts of the cytoplasm and are clearly distinguishable from other double-membrane structures, such as mitochondria (M). No specific AP formation could be observed in $\mathrm{MHCll}+/$ Ova - cells, however, the $\mathrm{CHO}$ treatment enhanced the density of the electron-dense vesicles (DV), (C) LC3B is present in electron-dense vesicles in sorted $\mathrm{MHCll}++/ \mathrm{Ova}-$ granulocytes. Sorted cells were stained with the LC3B antibody and protein A labeled with gold particles. LC3-positive electron-dense vesicles are indicated with arrows.

samples. Considering this and the magnitude of the observed differences, the CpG-induced upregulation appears to reflect the general potential of the cells to express these cytokines. It has previously been shown that, in seabream, granulocytes are a major cell type that produces the IL- $1 \beta$ protein (Chaves-Pozo et al., 2004). Therefore, in the current study, the high expression of this cytokine's mRNA in granulocytes indicates that these might be a key producer of IL- $1 \beta$ in salmon.

Unlike TNF which is expressed as a membrane bound protein, IL-1 $\beta$ lacks a secretory signal peptide and its mechanism of secretion has been debatable for a long time. It was shown in mammals as well as in seabream, that IL- $1 \beta$ was secreted within vesicles which appeared to be microvesicles (Pelegrin et al., 2004). However, more recently, it was suggested that a major route for secretion of IL-1 $\beta$ is through exosomes (Qu et al., 2007) - vesicles which are found in multivesicular bodies and which perform diverse immunomodulatory functions upon secretion (Denzer et al., 2000). Interestingly, it has been suggested that microautophagy, or a closely related mechanism, is involved in the formation of the exosomes (Buschow et al., 2005) and, it has been demonstrated that the IL-1 $\beta$ production and secretion depend on 
autophagy (Dupont et al., 2011; Harris et al., 2011). In view of this, the correlation between the high levels of LC3-II conversion and the IL-1 $\beta 1$ mRNA in the MHCII++ granulocytes suggests that these cells may be specialized for production of IL-1 $\beta$.

The results from the current study show that the expression of TNF2 and IL- $1 \beta$ correlates very well with the expression of receptors for cytokines of these families. The granulocytes expressed exceptionally high levels of IL1R1 and IL1R2, the latter of which is a non-signaling decoy receptor for IL-1 $\beta$, whereas the Ova+ cells upregulated highly DCR3 and OPG which are TNF family decoy receptors. The high upregulation of decoy receptors in cells that express high levels of cytokines for these receptors may serve to dampen excessive and potentially harmful effects of high concentrations of the cytokines in the microenvironment around the cells that secrete them.

Overall, the B-cells did not show particularly high expression of APC marker genes with the exception of CD208. In human, this molecule is specifically upregulated in mature DCs; however this trait does not seem to be phylogenetically conserved since in mouse it is present in other cells types (Salaun et al., 2003). The results shown in the current paper indicate that CD208 may serve as an excellent marker for salmon HK B-cells.

Compared to the other two MHCII+ cell types, the IgM+ cells expressed relatively low levels of proinflammatory cytokines. However, both the basal and the CpG-induced IFN- $\gamma$ expression were very high in these cells. Although, in mammals, IFN- $\gamma$ is predominately produced by NK and T-cells, certain subtypes of mammalian B lymphocytes are also known to express high levels of this cytokine (Harris et al., 2000).

It has been previously shown that trout HK harbors both early developing B-cells and antibody-secreting cells and serves as a major organ providing homing for mature plasma cells (Bromage

\section{REFERENCES}

Abi Abdallah, D. S., Egan, C. E., Butcher, B. A., and Denkers, E. Y. (2011). Mouse neutrophils are professional antigen-presenting cells programmed to instruct Th1 and Th17 T-cell differentiation. Int. Immunol. 23, 317-326. doi:10. 1093/intimm/dxr007

Aghaallaei, N., Bajoghli, B., Schwarz, H., Schorpp, M., and Boehm, T. (2010). Characterization of mononuclear phagocytic cells in medaka fish transgenic for a cxcr3a:gfp reporter. Proc. Natl. Acad. Sci. U.S.A. 107, 18079-18084. doi:10.1073/pnas.100046

7107

Agius, C., and Roberts, R. J. (2003). Melano-macrophage centres and their role in fish pathology. J. Fish Dis. 26, 499-509. doi:10.1046/j.13652761.2003.00485.x

Askew, D., Chu, R. S., Krieg, A. M., and Harding, C. V. (2000). CpG DNA induces maturation of dendritic cells with distinct effects on nascent and recycling MHC-II

et al., 2004; Zwollo et al., 2005). The CpG-induced downregulation of mIgM and PAX5 (a transcription factor expressed in the early/intermediate stages but not in the terminal stages of plasma cell differentiation) (Henderson and Calame, 1998) and the simultaneous upregulation of $\operatorname{sgM}$ in IgM+ cells indicate that the stimulation induces differentiation of mature plasma cells. It is not very likely that $\mathrm{CpG}$ stimulation alone, without activation through the B-cell receptor could activate this process. However, provided these cells have already been activated through the B-cell receptor, the CpGs may contribute to the process of their terminal differentiation. In this regard, it has been previously shown that although Ag stimulation alone can activate B-cell proliferation, a second stimulus, provided by innate immune receptors, such as TLRs is necessary for induction of Ab secretion (Vos et al., 2000).

In summary, the presented data indicates that salmon HK may serve as a major secondary lymphoid organ to which APCs loaded with Ag in the peripheral organs migrate. The description of distinct gene expression profiles in different HK cell types will help define markers for further characterization of different APC types in salmon and other teleost species. The correlation between the high expression of IL- $1 \beta 1$ and the high autophagy flux in HK granulocytes suggests that these cells might be specialized toward production and secretion of IL- $1 \beta 1$. The presented data also lay a ground for further studies aimed at elucidating the significance of autophagy for the immune response in teleosts.

\section{ACKNOWLEDGMENTS}

We thank prof. T. Johansen and Dr. T. Lamark (University of Troms $\varnothing$ ) for critical reading of the manuscript and helpful discussion. This study was supported by Aquaculture program of The Research Council of Norway (183196/S40 InNoVacc).

Cells Mol. Dis. 35, 398-403. doi:10.1016/j.bcmd.2005.08.005

Carramolino, L., Kremer, L., Goya, I., Varona, R., Buesa, J. M., Gutierrez, J., et al. (1999). Down-regulation of the beta-chemokine receptor CCR6 in dendritic cells mediated by TNFalpha and IL-4. J. Leukoc. Biol. 66, 837-844.

Chaves-Pozo, E., Pelegrin, P., GarciaCastillo, J., Garcia-Ayala, A., Mulero, V., and Meseguer, J. (2004). Acidophilic granulocytes of the marine fish gilthead seabream (Sparus aurata L.) produce interleukinlbeta following infection with Vibrio anguillarum. Cell Tissue Res. 316, 189-195. doi:10.1007/s00441004-0875-9

Cuesta, A., Angeles Esteban, M., and Meseguer, J. (2006). Cloning, distribution and up-regulation of the teleost fish MHC class II alpha suggests a role for granulocytes as antigen-presenting cells. Mol. Immunol. 43, 1275-1285. doi:10.1016/j.molimm.2005.07.004

Denzer, K., Kleijmeer, M. J., Heijnen, H. F., Stoorvogel, W., and Geuze, H.
J. (2000). Exosome: from internal vesicle of the multivesicular body to intercellular signaling device. J. Cell. Sci. 113(Pt 19), 3365-3374.

Dupont, N., Jiang, S., Pilli, M., Ornatowski, W., Bhattacharya, D., and Deretic, V. (2011). Autophagy-based unconventional secretory pathway for extracellular delivery of IL1beta. EMBO J. 30, 4701-4711. doi:10.1038/emboj.2011.398

Hamilos, D. L. (1989). Antigen presenting cells. Immunol. Res. 8, 98-117. doi:10.1007/BF02919073

Harris, D. P., Haynes, L., Sayles, P. C., Duso, D. K., Eaton, S. M., Lepak, N. M., et al. (2000). Reciprocal regulation of polarized cytokine production by effector $\mathrm{B}$ and $\mathrm{T}$ cells. Nat. Immunol. 1, 475-482. doi:10.1038/82717

Harris, J., Hartman, M., Roche, C., Zeng, S. G., O’Shea, A., Sharp, F. A., et al. (2011). Autophagy controls IL-1beta secretion by targeting pro-IL-lbeta for degradation. J. Biol. Chem. 286, 9587-9597. doi:10.1074/jbc.M110.20 2911 
Hartmann, G., Weiner, G. J., and Krieg, A. M. (1999). CpG DNA: a potent signal for growth, activation, and maturation of human dendritic cells. Proc. Natl. Acad. Sci. U.S.A. 96, 9305-9310. doi:10.1073/pnas.96.16.9305

Henderson, A., and Calame, K. (1998). Transcriptional regulation during B cell development. Annu. Rev. Immunol. 16, 163-200. doi:10. 1146/annurev.immunol.16.1.163

Iliev, D. B., Jorgensen, S. M., Rode, M., Krasnov, A., Harneshaug, I., and Jørgensen, J. B. (2010). CpG-induced secretion of MHCIIbeta and exosomes from salmon (Salmo salar) APCs. Dev. Comp. Immunol. 34, 29-41. doi:10.1016/j.dci.2009.07.009

Iliev, D. B., Sobhkhez, M., Fremmerlid, K., and Jorgensen, J. B. (2011). MyD88 interacts with interferon regulatory factor (IRF) 3 and IRF7 in Atlantic salmon (Salmo salar): transgenic SsMyD88 modulates the IRFinduced type I interferon response and accumulates in aggresomes. J. Biol. Chem. 286, 42715-42724. doi:10.1074/jbc.M111.293969

Jovic, M., Sharma, M., Rahajeng, J., and Caplan, S. (2010). The early endosome: a busy sorting station for proteins at the crossroads. Histol. Histopathol. 25, 99-112.

Kaisho, T., and Akira, S. (2003). Regulation of dendritic cell function through Toll-like receptors. Curr. Mol. Med. 3, 373-385. doi:10.2174/1566524033479366

Klein, L., Munz, C., and Lunemann, J. D. (2010). Autophagymediated antigen processing in CD4(+) T cell tolerance and immunity. FEBS Lett. 584, 1405-1410. doi:10.1016/j.febslet.2010.01.008

Klinman, D. M. (2003). CpG DNA as a vaccine adjuvant. Expert Rev. Vaccines 2, 305-315. doi:10.1586/14760584.2.2.305

Klionsky, D. J., Abeliovich, H., Agostinis, P., Agrawal, D. K., Aliev, G., Askew, D. S., et al. (2008). Guidelines for the use and interpretation of assays for monitoring autophagy in higher eukaryotes. Autophagy 4, 151-175.

Kobayashi, S., Voyich, J., Burlak, C., and Deleo, F. (2005). Neutrophils in the innate immune response. Arch.
Immunol. Ther. Exp. (Warsz.) 53, 505-517.

Lagos, L. X., Iliev, D. B., Helland, R., Rosemblatt, M., and Jorgensen, J. B. (2012). CD40L - a costimulatory molecule involved in the maturation of antigen presenting cells in Atlantic salmon (Salmo salar). Dev. Comp. Immunol. 38, 416-430. doi:10.1016/j.dci.2012.07.011

Lim, J. P., and Gleeson, P. A. (2011). Macropinocytosis: an endocytic pathway for internalising large gulps. Immunol. Cell Biol. 89, 836-843. doi:10.1038/icb. 2011.20

Lovy, J., Savidant, G. P., Speare, D. J., and Wright, G. M. (2009). Langerin/CD207 positive dendriticlike cells in the haemopoietic tissues of salmonids. Fish Shellfish Immunol. 27, 365-368. doi:10.1016/j.fsi.2009.01.006

Lugo-Villarino, G., Balla, K. M., Stachura, D. L., Banuelos, K., Werneck, M. B., and Traver, D. (2010). Identification of dendritic antigen-presenting cells in the zebrafish. Proc. Natl. Acad. Sci. U.S.A. 107, 15850-15855. doi:10.1073/pnas.1000494107

Miller, N. W., Deuter, A., and Clem, L. W. (1986). Phylogeny of lymphocyte heterogeneity: the cellular requirements for the mixed leucocyte reaction with channel catfish. Immunology 59, 123-128.

Mizushima, N. (2007). Autophagy: process and function. Genes Dev. 21, 2861-2873. doi:10.1101/gad.1599207

Pancer, Z., and Cooper, M. D. (2006). The evolution of adaptive immunity. Annu. Rev. Immunol. 24, 497-518. doi:10.1146/annurev.immunol.24. 021605.090542

Pelegrin, P., CHAVES-Pozo, E., Mulero, V., and Meseguer, J. (2004). Production and mechanism of secretion of interleukin-lbeta from the marine fish gilthead seabream. Dev. Comp. Immunol. 28, 229-237. doi:10.1016/j.dci.2003.08.002

Qu, Y., Franchi, L., Nunez, G., and Dubyak, G. R. (2007). Nonclassical IL-1 beta secretion stimulated by $\mathrm{P} 2 \times 7$ receptors is dependent on inflammasome activation and correlated with exosome release in murine macrophages. J. Immunol 179, 1913-1925.

Salaun, B., de Saint-Vis, B., ClairMoninot, V., Pin, J. J., BarthelemyDubois, C., Kissenpfennig, A., et al. (2003). Cloning and characterization of the mouse homologue of the human dendritic cell maturation marker CD208/DC-LAMP. Eur. J. Immunol. 33, 2619-2629. doi:10.1002/eji.200324175

Sallusto, F., Cella, M., Danieli, C. and Lanzavecchia, A. (1995). Dendritic cells use macropinocytosis and the mannose receptor to concentrate macromolecules in the major histocompatibility complex class II compartment: downregulation by cytokines and bacterial products. J. Exp. Med. 182, 389-400. doi:10.1084/jem.182.2.389

Strandskog, G., Skjæveland, I., Ellingsen, T., and Jørgensen, J. B. (2008). Double-stranded RNA- and CpG DNA-induced immune responses in Atlantic salmon: comparison and synergies. Vaccine 26, 4704-4715. doi:10.1016/j.vaccine.2008.06.054

Thery, C., and Amigorena, S. (2001). The cell biology of antigen presentation in dendritic cells. Curr. Opin. Immunol. 13, 45-51. doi:10.1016/S0952-7915(00)00 180-1

Tokuyasu, K. T. (1986). Application of cryoultramicrotomy to immunocytochemistry. J. Microsc. 143, 139-149. doi:10.1111/j.13652818.1986.tb02772.x

Tsujii, T., and Seno, S. (1990). Melano-macrophage centers in the aglomerular kidney of the sea horse (teleosts): morphologic studies on its formation and possible function. Anat. Rec. 226, 460-470. doi:10.1002/ar.1092260408

Ushio, H., Ueno, T., Kojima, Y. Komatsu, M., Tanaka, S., Yamamoto A., et al. (2011). Crucial role for autophagy in degranulation of mast cells. J. Allergy Clin. Immunol. 127, 1267-1276. doi:10.1016/j.jaci.2010.12.1078

Vos, Q., Lees, A., Wu, Z. Q., Snapper, C. M., and Mond, J. J. (2000). B-cell activation by T-cellindependent type 2 antigens as an integral part of the humoral immune response to pathogenic microorganisms. Immunol. Rev. 176, 154-170. doi:10.1034/j.1600065X.2000.00607.x

Vyas, J. M., Van der Veen, A. G., and Ploegh, H. L. (2008). The known unknowns of antigen processing and presentation. Nat. Rev. Immunol. 8 , 607-618. doi:10.1038/nri2368

Webster, P., and Webster, A. (2007). Cryosectioning fixed and cryoprotected biological material for immunocytochemistry. Methods Mol. Biol. 369, 257-289. doi:10.1007/978-1-59745-294-6_13

Wileman, T., Harding, C., and Stahl, P. (1985). Receptor-mediated endocytosis. Biochem. J. 232, 1-14.

Wittamer, V., Bertrand, J. Y., Gutschow, P. W., and Traver, D. (2011). Characterization of the mononuclear phagocyte system in zebrafish. Blood 117, 7126-7135. doi:10.1182/blood2010-11-321448

Zwollo, P., Cole, S., Bromage, E., and Kaattari, S. (2005). B cell heterogeneity in the teleost kidney: evidence for a maturation gradient from anterior to posterior kidney. $J$. Immunol. 174, 6608-6616.

Conflict of Interest Statement: The authors declare that the research was conducted in the absence of any commercial or financial relationships that could be construed as a potential conflict of interest.

Received: 16 April 2013; accepted: 22 May 2013; published online: 06 June 2013.

Citation: Iliev DB, Thim H, Lagos L, Olsen R and Jørgensen JB (2013) Homing of antigen-presenting cells in head kidney and spleen - salmon head kidney hosts diverse APC types. Front. Immunol. 4:137. doi: 10.3389/fimmu.2013.00137 This article was submitted to Frontiers in Antigen Presenting Cell Biology, a specialty of Frontiers in Immunology. Copyright () 2013 Iliev, Thim, Lagos, Olsen and Jorgensen. This is an openaccess article distributed under the terms of the Creative Commons Attribution License, which permits use, distribution and reproduction in other forums, provided the original authors and source are credited and subject to any copyright notices concerning any third-party graphics etc. 